\title{
Monoterpenoid Indole Alkaloids from Inadequately Dried Leaves of Alstonia scholaris
}

\author{
Xu-Jie Qin · Yun-Li Zhao $\cdot$ Chang-Wei Song • \\ Bei Wang $\cdot$ Ying-Ying Chen $\cdot$ Lu Liu $\cdot$ \\ Qiong Li $\cdot$ Dan Li $\cdot$ Ya-Ping Liu $\cdot$ Xiao-Dong Luo
}

Received: 17 July 2015/ Accepted: 23 July 2015/Published online: 18 August 2015

(C) The Author(s) 2015. This article is published with open access at Springerlink.com

\begin{abstract}
Six new indole alkaloids, named alstoniascholarines L-Q (1-6), together with nineteen known analogues were isolated from the inadequately dried leaves of Alstonia scholaris. Their structures were elucidated on the basis of extensive analysis of spectroscopic data and by comparison of their physical and spectroscopic data with the literature values. In addition, the new alkaloids were tested for their cytotoxic and neurite outgrowth-promoting activities.
\end{abstract}

Keywords Alstonia scholaris $\cdot$ Inadequately dried leaves $\cdot$ Indole alkaloids $\cdot$ Alstoniascholarine $\cdot$ Bioactivities

\section{Introduction}

Plants of the genus Alstonia (Apocynaceae), which are usually shrubs or trees, grow mainly in the tropical regions of Africa and Asia. A. scholaris has been historically used to treat chronic respiratory diseases in 'dai' ethnopharmacy in Yunnan province, People's Republic of China. Previous phytochemical and phar-

Electronic supplementary material The online version of this article (doi:10.1007/s13659-015-0066-2) contains supplementary material, which is available to authorized users.

X.-J. Qin · Y.-L. Zhao - C.-W. Song - B. Wang · Y.-Y. Chen · L. Liu · Q. Li · D. Li · Y.-P. Liu $(\bowtie) \cdot$ X.-D. Luo $(\bowtie)$

State Key Laboratory of Phytochemistry and Plant Resources in West China, Kunming Institute of Botany, Chinese Academy of Sciences, Kunming 650201, People's Republic of China e-mail: liuyaping@mail.kib.ac.cn

X.-D. Luo

e-mail: xdluo@mail.kib.ac.cn

X.-J. Qin · B. Wang · Y.-Y. Chen · L. Liu · Q. Li · D. Li University of Chinese Academy of Sciences, Beijing 100049, People's Republic of China macological studies on this species afforded a number of structurally diverse indole alkaloids [1-5] with various bioactivities, such as antineoplastic [6], antibacterial [7], anti-inflammatory and analgesic effects [8], and broncho-vasodilatory [9] activities. The leaves of A. scholaris are usually collected and dried by exposed to sunshine in an open yard. However, some leaves of A. scholaris might not be dried in time because of rainy days in Pu'er city. Then, the green color of these leaves might fade in couples of day even they were died finally. Whether these leaves can be used for medical raw material is still unknown, which encouraged us to carried out HPLC analysis of total alkaloids from the inadequately dried leaves of A. scholaris. The results indicated that picrinine, the major bioactive compound was decreased remarkably and more peaks were appeared in the HPLC fingerprint profile of inadequately dried leaves (see Supplementary data). Correspondingly, the anti-tussive efficacy reduced significantly (Table 1). In our continuing efforts to search for structurally interesting and bioactive indoles of this plant [10-15], the inadequately dried leaves of $A$. scholaris were investigated. As a result, six new indole alkaloids, alstoniascholarines L-Q (1-6), along with nineteen known analogues were isolated. We report herein the isolation, structural elucidation and bioactivities of alkaloids. 
Table 1 Effect of the different alkaloid extracts on ammonia-induced cough in mice

\begin{tabular}{llcl}
\hline Group & Dose $(\mathrm{mg} / \mathrm{kg})$ & Frequency of cough & Inhibition $(\%)$ \\
\hline Control & & $31.3 \pm 6.5$ & - \\
Codeine phosphate & 30 & $7.0 \pm 2.5^{* *}$ & 77.6 \\
Alkaloids from the dried leaves & 20 & $13.1 \pm 4.8^{* *}$ & 58.0 \\
& 10 & $17.0 \pm 5.6^{* *}$ & 45.6 \\
Alkaloids from the inadequately dried leaves & 20 & $19.4 \pm 3.9^{* *}$ & 38.0 \\
& 10 & $22.8 \pm 7.1^{*}$ & 27.2 \\
\hline
\end{tabular}

Values expressed as mean $\pm \operatorname{SEM}(n=10),{ }^{*} P<0.05$ and ${ }^{* *} P<0.01$ for comparison of treated groups with control

Table $2{ }^{1} \mathrm{H}$ and ${ }^{13} \mathrm{C}$ NMR spectroscopic data for alkaloids $\mathbf{1}-\mathbf{3}$ in $\mathrm{CD}_{3} \mathrm{OD}$

\begin{tabular}{|c|c|c|c|c|c|c|}
\hline \multirow[t]{2}{*}{ Position } & \multicolumn{2}{|l|}{$\mathbf{1}^{\mathrm{a}}$} & \multicolumn{2}{|l|}{$2^{\mathrm{a}}$} & \multicolumn{2}{|l|}{$3^{\mathrm{b}}$} \\
\hline & $\delta_{\mathrm{C}}$ & $\delta_{\mathrm{H}}(J, \mathrm{~Hz})$ & $\delta_{\mathrm{C}}$ & $\delta_{\mathrm{H}}(J, \mathrm{~Hz})$ & $\delta_{\mathrm{C}}$ & $\delta_{\mathrm{H}}(J, \mathrm{~Hz})$ \\
\hline 2 & 109.2 & & 109.0 & & 84.5 & \\
\hline 3 & 51.2 & 3.63 br d (5.7) & 51.4 & 3.64 br d (5.8) & 68.5 & 3.66 br d (3.1) \\
\hline 5 & 178.1 & & 178.1 & & 150.7 & $8.81 \mathrm{~d}(4.8)$ \\
\hline $6 a$ & 44.2 & $3.73 \mathrm{~d}(18.0)$ & 44.0 & $3.78 \mathrm{~d}(18.0)$ & 118.4 & $7.49 \mathrm{~d}(4.8)$ \\
\hline $6 b$ & & $2.77 \mathrm{~d}(18.0)$ & & $2.75 \mathrm{~d}(18.0)$ & & \\
\hline 7 & 51.2 & & 51.2 & & $\mathrm{nd}^{\mathrm{c}}$ & \\
\hline 8 & 136.7 & & 136.6 & & 128.1 & \\
\hline 9 & 124.3 & $7.20 \mathrm{~d}(7.5)$ & 124.2 & $7.20 \mathrm{~d}(7.5)$ & 129.2 & $9.19 \mathrm{~d}(8.6)$ \\
\hline 10 & 121.1 & $6.79 \mathrm{t}(7.6)$ & 121.0 & $6.80 \mathrm{t}(7.5)$ & 128.0 & $7.69 \mathrm{t}(8.4)$ \\
\hline 11 & 130.2 & $7.08 \mathrm{t}(7.5)$ & 130.2 & $7.08 \mathrm{t}(7.7)$ & 131.0 & $7.79 \mathrm{t}(8.2)$ \\
\hline 12 & 110.3 & $6.62 \mathrm{~d}(7.8)$ & 110.3 & $6.62 \mathrm{~d}(7.8)$ & 129.7 & $8.06 \mathrm{~d}(8.3)$ \\
\hline 13 & 148.7 & & 148.7 & & 150.1 & \\
\hline $14 \mathrm{a}$ & 20.7 & 1.92 ddd $(8.0,6.0,2.0)$ & 21.5 & 2.00 ddd $(8.1,6.1,2.0)$ & 26.0 & $2.22 \mathrm{~d}(13.8)$ \\
\hline $14 \mathrm{~b}$ & & $1.77 \mathrm{dd}(14.6,4.3)$ & & $1.77 \mathrm{dd}(14.5,4.3)$ & & $1.98 \mathrm{dt}(13.8)$ \\
\hline 15 & 32.3 & $2.83 \mathrm{~m}$ & 34.3 & $2.62 \mathrm{~m}$ & 42.5 & $3.11 \mathrm{~m}$ \\
\hline 16 & 49.1 & $3.23 \mathrm{~d}(11.5)$ & 48.6 & $3.28 \mathrm{~d}(11.5)$ & 55.7 & $3.36 \mathrm{~d}(7.9)$ \\
\hline 17 & 178.8 & & 178.7 & & 176.5 & \\
\hline 18 & 17.5 & $1.20 \mathrm{~d}(6.5)$ & 17.4 & $1.20 \mathrm{~d}(6.5)$ & 17.5 & $1.26 \mathrm{~d}(6.5)$ \\
\hline 19 & 68.9 & $3.72 \mathrm{q}(6.5)$ & 71.3 & $3.78 \mathrm{q}(6.5)$ & 70.4 & $3.81 \mathrm{q}(6.5)$ \\
\hline 20 & 92.8 & & 92.1 & & 92.0 & \\
\hline $21 \mathrm{a}$ & 45.7 & $3.06 \mathrm{~d}(13.3)$ & 44.6 & $3.24 \mathrm{~d}(13.4)$ & 54.2 & $2.94 \mathrm{~d}(12.8)$ \\
\hline $21 b$ & & $2.68 \mathrm{~d}(13.3)$ & & $2.73 \mathrm{~d}(13.4)$ & & $2.79 \mathrm{~d}(12.8)$ \\
\hline$N$-Me & & & & & 46.2 & $2.65 \mathrm{~s}$ \\
\hline
\end{tabular}

${ }^{\text {a }}$ Recorded at 400 and $100 \mathrm{MHz}$

b Recorded at 600 and $150 \mathrm{MHz}$

${ }^{c}$ Not detected

\section{Results and Discussion}

Alkaloid 1 was obtained as a white amorphous powder. The HREIMS spectrum showed a quasi-molecular ion peak at $m / z 356.1366[\mathrm{M}]^{+}$(calcd for $\mathrm{C}_{19} \mathrm{H}_{20} \mathrm{~N}_{2} \mathrm{O}_{5}, 356.1372$ ) from which, in conjunction with the ${ }^{13} \mathrm{C}$ NMR data, the molecular formula was determined to be $\mathrm{C}_{19} \mathrm{H}_{20} \mathrm{~N}_{2} \mathrm{O}_{5}$, requiring 11 indices of hydrogen deficiency. The UV absorption maxima 204, 240, and $298 \mathrm{~nm}$ suggested the presence of an indole chromophore, while the IR spectrum of 1 indicated the presence of indolic amino $\left(3440 \mathrm{~cm}^{-1}\right)$, ester carbonyl $\left(1748 \mathrm{~cm}^{-1}\right)$, and aromatic ring (1612 and $1485 \mathrm{~cm}^{-1}$ ) functionalities, respectively. The ${ }^{13} \mathrm{C}$ NMR and DEPT spectra (Table 2) for $\mathbf{1}$ revealed 19 carbon 
signals, including characteristic signals due to an indole ring $\left[\delta_{\mathrm{C}} 109.2(\mathrm{~s}, \mathrm{C}-2), 51.2(\mathrm{~s}, \mathrm{C}-7), 136.7(\mathrm{~s}, \mathrm{C}-8), 124.3\right.$ (d, C-9), 121.1 (d, C-10), 130.2 (d, C-11), 110.3 (d, C-12), and 148.7 (s, C-13)], two ester carbonyls $\left(\delta_{\mathrm{C}} 178.1\right.$ and $178.8)$, one oxygen-bearing quaternary carbon $\left(\delta_{\mathrm{C}} 92.8\right)$, four methines $\left(\delta_{\mathrm{C}} 68.9,51.2,49.1\right.$, and 32.3), three methylenes ( $\delta_{\mathrm{C}} 45.7,44.2$, and 20.7$)$, and one methyl group $\left(\delta_{\mathrm{C}} 17.5\right)$.

The ${ }^{1} \mathrm{H}-{ }^{1} \mathrm{H}$ COSY spectrum of $\mathbf{1}$ disclosed the presence of three structural fragments, a (C-9-C-12), b (C-3-C-14-C15-C-16), and c (C-18-C-19), as shown in Fig. 2. The position of functional groups and the skeleton of alkaloid $\mathbf{1}$ were assigned by its $\mathrm{HMBC}$ data. In the $\mathrm{H} \mathrm{MBC}$ spectrum, the correlations of $\delta_{\mathrm{H}} 3.73$ and 2.77 (both d, $J=18.0 \mathrm{~Hz}$, $\mathrm{H}_{2}-6$ ) with $\delta_{\mathrm{C}} 109.2$ (s, C-2), 178.1 (s, C-5) and 51.2 (s, C-7), indicated the presence of a five-membered lactone ring $\mathrm{E}$ which was formed by the connection of C-5 and C-2 via an oxygen atom. Besides, the HMBC correlations of $\mathrm{H}-16$ with C-7 and of $\delta_{\mathrm{H}} 3.63(1 \mathrm{H}$, br d, $J=5.7 \mathrm{~Hz}, \mathrm{H}-3)$ with C-2 suggested the formation of a six-membered ring $\mathrm{C}$. The relative downfield shifts of $\delta_{\mathrm{C}} 51.2$ (d, C-3) and 45.7 (t, C-21) required that they both be connected to a nitrogen atom. Likewise, the HMBC correlations of $\delta_{\mathrm{H}} 2.68(1 \mathrm{H}, \mathrm{d}$, $J=13.3 \mathrm{~Hz}, \mathrm{H}-21 \mathrm{~b}$ ) with $\delta_{\mathrm{C}} 32.3$ (d, C-15), 92.8 (s, C-20) and $\mathrm{C}-3$, and of $\delta_{\mathrm{H}} 2.83(1 \mathrm{H}, \mathrm{m}, \mathrm{H}-15)$ with C-20 established the occurrence of another six-membered ring. Moreover, considering the last one degree of unsaturation in $\mathbf{1}$, another ring should be constructed. The key HMBC correlations of $\mathrm{H}-16$ with $\mathrm{C}-17$ and $\mathrm{C}-20$ revealed that another five-membered lactone ring was present between C-17 and C-20. Finally, a linkage of C-18/19/20 was deduced from HMBC correlations of Me-18 $\left(\delta_{\mathrm{H}} 1.20, \mathrm{~d}, J=6.5 \mathrm{~Hz}\right)$ with $\delta_{\mathrm{C}} 68.9$ (d, C-19) and C-20. On the basis of the aforementioned information, the planar structure of $\mathbf{1}$ was elucidated as an monoterpenoid indole alkaloid with a rare 6/5/6/6/5/5 fused ring system. The stereochemistry was then considered. In the ROESY spectrum, the correlations of $\mathrm{H}-3 / \mathrm{H}_{2}-14, \mathrm{H}_{2}-14 / \mathrm{H}-$ 15 , and $\mathrm{H}-15 / \mathrm{H}-16$ were observed, indicating that they should be placed on the same side. However, it still could not determine the configuration for such complicated ring system. According to the similarities between the NMR data of 1 and the recently reported bio-relationship (Scheme 1) of alstolactines A-C [14], the configuration of $\mathbf{1}$ was assigned as $2 R, 3 S, 7 R, 15 R, 16 R, 19 R, 20 S$. This was further confirmed by the comparison of its CD spectrum with that of alstolactine A (Fig. 3). It is worthy to note that alstolactines A-C were also isolated from the leaves of $A$. scholaris and their absolute configurations were determined by the X-ray diffraction. On the basis of the above results, the structure of alkaloid 1 was established to be as shown in Fig. 1 and named alstoniascholarine L.

Alkaloid 2 was shown to have the same molecular formula of $\mathrm{C}_{19} \mathrm{H}_{20} \mathrm{~N}_{2} \mathrm{O}_{5}$ as that of $\mathbf{1}$ based on its HREIMS spectrum $\left(m / z, 356.1358[\mathrm{M}]^{+}\right.$, calcd for $\mathrm{C}_{19} \mathrm{H}_{20} \mathrm{~N}_{2} \mathrm{O}_{5}$, 356.1372). The ${ }^{1} \mathrm{H}$ and ${ }^{13} \mathrm{C}$ NMR spectral data (Table 2) of 2 were almost identical with those of $\mathbf{1}$, except for the carbon signals of C-15, C-19, and C-21, which indicated that 2 could be a 19-epimer of $\mathbf{1}$. Following a similar analysis of the ${ }^{1} \mathrm{H},{ }^{13} \mathrm{C}$ and $2 \mathrm{D}$ NMR spectroscopic data as described before, the gross structure of alkaloid 2 was the same as that of $\mathbf{1}$. The well matched CD curves of alkaloids $\mathbf{1}$ and $\mathbf{2}$ (Fig. 3) proposed the absolute configurations of $\mathbf{1}$ and 2 . The absolute configurations of $2 R, 3 S, 7 R, 15 R, 16 R$, $20 S$ were those commonly accepted from biogenetic point of view. However, the configuration of C-19 was assigned as $19 R$ rather than $19 S$ based on its similar NMR data with that of alstolactine B [14]. Therefore, the structure of 2 was characterized as shown in Fig. 1 and named alstoniascholarine $\mathrm{M}$.

Alkaloid 3 was determined to have the molecular formula of $\mathrm{C}_{20} \mathrm{H}_{22} \mathrm{~N}_{2} \mathrm{O}_{4}$ from an HREIMS ion peak at $\mathrm{m} / \mathrm{z} 354.1577$ $\left([\mathrm{M}]^{+}\right)$. The ${ }^{1} \mathrm{H}$ and ${ }^{13} \mathrm{C}$ NMR spectroscopic data (Table 2) of 3 showed its structure resembling that of alstolactine A. The main difference between them was the presence of two olefinic carbon signals $\left(\delta_{\mathrm{C}} 118.4\right.$ and 150.7) in alkaloid 3 and the absence of the lactone $\left(\delta_{\mathrm{C}} 177.2\right)$ and methylene $\left(\delta_{\mathrm{C}} 43.8\right)$ groups in 2 . The HMBC correlation of $\mathrm{H}-5\left(\delta_{\mathrm{H}}\right.$ $7.49, \mathrm{~d}, J=4.8 \mathrm{~Hz})$ with $\mathrm{C}-7\left(\delta_{\mathrm{C}} 84.5\right)$ and a ${ }^{1} \mathrm{H}-{ }^{1} \mathrm{H}$ COSY correlation between $\mathrm{H}-5\left(\delta_{\mathrm{H}} 7.49\right)$ and $\mathrm{H}-6\left(\delta_{\mathrm{H}} 8.81\right)$ allowed the location of the double bond was at C-5 and C-6. Other parts of $\mathbf{3}$ were identical to those of alstolactine A, as supported by its HSQC, HMBC, and COSY experimental data. The configuration of $\mathrm{C}-19$ was determined to be $R$ based on the chemical shifts of C-19 $\left(\delta_{\mathrm{C}} 70.4\right)$ and C-20 $\left(\delta_{\mathrm{C}} 92.0\right)$, which were in agreement to those of alstolactine $\mathrm{A}\left(\delta_{\mathrm{C}} 69.2\right.$ and 92.1$)$ rather than those of alstolactine $\mathrm{B}\left(\delta_{\mathrm{C}}\right.$ 71.7 and 91.4). The other configurations of $\mathbf{3}$ were assigned to be the same as those of $\mathbf{1}$ based on their same biogenetic pathway (Scheme 1) and similar NMR data. Accordingly, the structure of $\mathbf{3}$ was elucidated as shown in Fig. 1 and named alstoniascholarine $\mathrm{N}$.

Biosynthetically, the three related alkaloids might be derived from the precursor picrinine, which was also isolated as a main chemical constituent in this experiment. A plausible biogenetic pathway for 1-3 suggested that a Hoffmann degradation led to the formation of a dihydrofuran intermediate A. Further oxidation would yield a lactone derivative B. Then, epoxidation at C-20-C-19 double bond, followed by ring opening could produce another lactonic F-ring. Subsequently, alkaloids 1 and 2 would finally be obtained via demethylation of the methyl N(4)-Me of alstolactines A and B. Coincidently, alkaloid 3 might also derive from intermediate $\mathbf{A}$ without oxidation and demethylation.

Alkaloid 4, isolated as a white amorphous powder, had the molecular formula $\mathrm{C}_{20} \mathrm{H}_{24} \mathrm{~N}_{2} \mathrm{O}_{4}$, as established by 


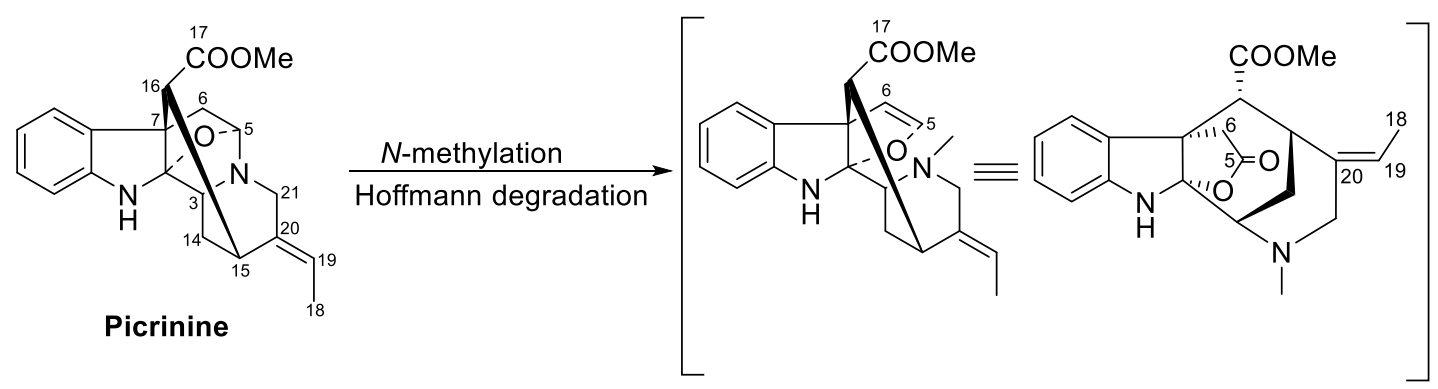

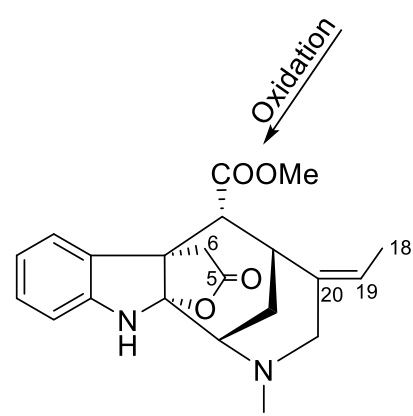

B

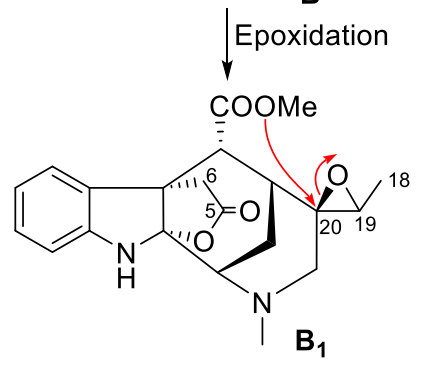

$\mathrm{H}_{2} \mathrm{O}$

Ring opening

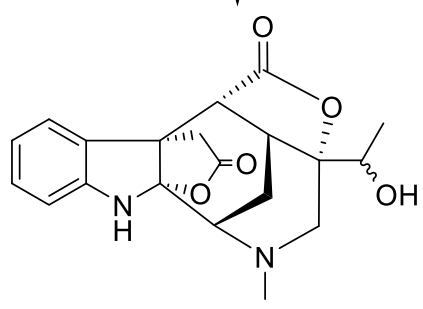

Alstolactines A and B
A

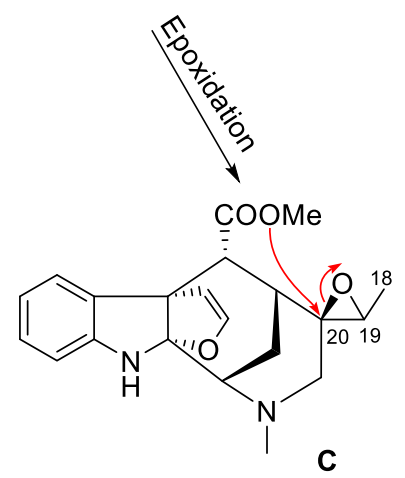

C

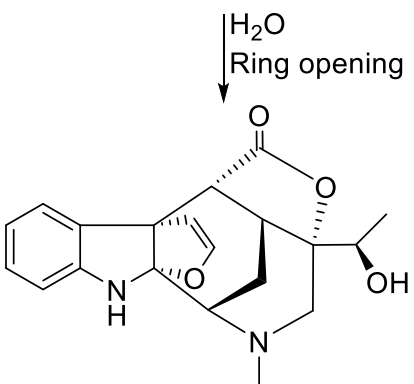

3

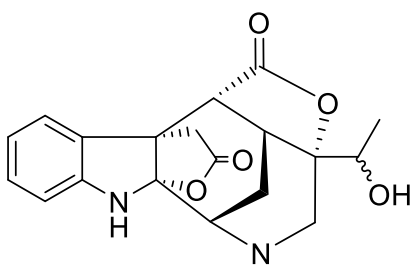

1 and 2

Scheme 1 Putative biosynthetic pathway of alkaloids 1-3 from picrinine

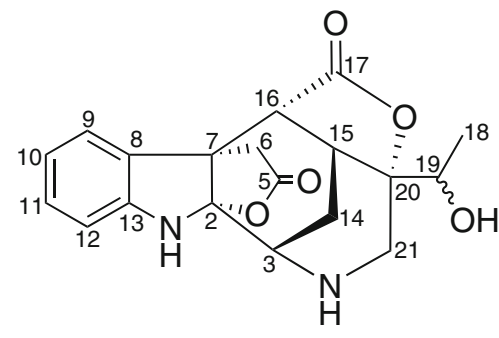

$119 R$

$219 S$

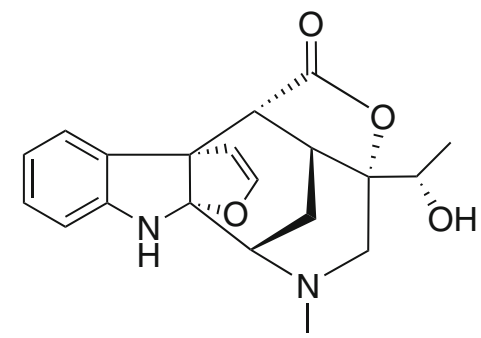

3

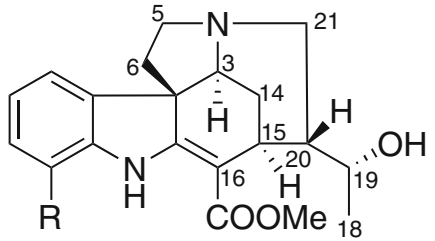

$4 \mathrm{R}=\mathrm{OH}$

$5 \mathrm{R}=\mathrm{OH} \quad \mathrm{N}(4) \rightarrow \mathrm{O}$

$6 \mathrm{R}=$ OMe $N(4) \rightarrow \mathrm{O}$

Fig. 1 Structures of alkaloids 1-6 
Table $3{ }^{1} \mathrm{H}$ and ${ }^{13} \mathrm{C}$ NMR spectroscopic data for alkaloids 4-6 in $\mathrm{CD}_{3} \mathrm{OD}^{\mathrm{a}}$

\begin{tabular}{|c|c|c|c|c|c|c|}
\hline \multirow[t]{2}{*}{ Position } & \multicolumn{2}{|l|}{4} & \multicolumn{2}{|l|}{5} & \multicolumn{2}{|l|}{6} \\
\hline & $\delta_{\mathrm{C}}$ & $\delta_{\mathrm{H}}(J \mathrm{inHz})$ & $\delta_{\mathrm{C}}$ & $\delta_{\mathrm{H}}(J$ in $\mathrm{Hz})$ & $\delta_{\mathrm{C}}$ & $\delta_{\mathrm{H}}(J$ inHz $)$ \\
\hline 2 & 165.6 & & 164.8 & & 166.2 & \\
\hline 3 & 61.8 & $4.58 \mathrm{br} \mathrm{s}$ & 78.0 & $4.83 \mathrm{br} \mathrm{s}$ & 78.4 & $4.33 \mathrm{br} \mathrm{s}$ \\
\hline $5 \mathrm{a}$ & 53.0 & $3.70 \mathrm{~m}$ & 66.8 & $4.082 \mathrm{H} \mathrm{m}$ & 69.1 & $3.75 \mathrm{~m}$ \\
\hline $5 b$ & & $3.43 \mathrm{~m}$ & & & & $3.68 \mathrm{~m}$ \\
\hline $6 a$ & 43.0 & $2.56 \mathrm{~m}$ & 41.0 & $2.59 \mathrm{~m}$ & 41.0 & $2.50 \mathrm{~m}$ \\
\hline $6 \mathrm{~b}$ & & $2.19 \mathrm{~m}$ & & $2.38 \mathrm{~m}$ & & $2.24 \mathrm{~m}$ \\
\hline 7 & 57.9 & & 57.1 & & 57.0 & \\
\hline 8 & 134.5 & & 134.1 & & 135.2 & \\
\hline 9 & 113.0 & $6.89 \mathrm{~d}(7.5)$ & 113.0 & $7.00 \mathrm{~d}(7.4)$ & 114.0 & $7.10 \mathrm{~d}(7.4)$ \\
\hline 10 & 123.7 & $6.82 \mathrm{t}(7.8)$ & 123.8 & $6.85 \mathrm{t}(7.8)$ & 123.8 & $6.97 \mathrm{t}(8.0)$ \\
\hline 11 & 117.4 & $6.74 \mathrm{~d}(8.1)$ & 117.6 & $6.76 \mathrm{~d}(8.1)$ & 112.5 & $6.92 \mathrm{~d}(8.2)$ \\
\hline 12 & 143.3 & & 143.4 & & 146.2 & \\
\hline 13 & 132.7 & & 132.8 & & 133.6 & \\
\hline $14 \mathrm{a}$ & 26.5 & $2.37 \mathrm{dt}(14.6,3.4)$ & 25.9 & $2.62 \mathrm{~m}$ & 25.8 & 2.65 br d (14.5) \\
\hline $14 \mathrm{~b}$ & & $1.35 \mathrm{dt}(14.6,2.5)$ & & 1.47 br d (14.8) & & 1.29 br d (14.5) \\
\hline 15 & 25.8 & $3.32 \mathrm{~m}$ & 25.1 & $3.43 \mathrm{br} \mathrm{s}$ & 25.7 & 3.36 br s \\
\hline 16 & 105.3 & & 105.0 & & 105.6 & \\
\hline 18 & 20.5 & $1.32 \mathrm{~d}(6.6)$ & 20.8 & $1.37 \mathrm{~d}(6.4)$ & 20.8 & $1.33 \mathrm{~d}(6.4)$ \\
\hline 19 & 69.0 & $3.82 \mathrm{~m}$ & 68.4 & $3.91 \mathrm{~m}$ & 69.0 & $3.95 \mathrm{~m}$ \\
\hline 20 & 42.0 & $2.10 \mathrm{~m}$ & 44.4 & $2.13 \mathrm{~m}$ & 44.8 & $1.97 \mathrm{~m}$ \\
\hline $21 \mathrm{a}$ & 48.5 & $3.48 \mathrm{dd}(13.5,11.7)$ & 64.1 & $4.00 \mathrm{dd}(13.4,6.1)$ & 66.3 & $3.71 \mathrm{dd}(13.6,6.1)$ \\
\hline $21 b$ & & $3.22 \mathrm{dd}(13.5,6.2)$ & & $3.81 \mathrm{dd}(13.0,10.6)$ & & $3.47 \mathrm{dd}(13.4,9.3)$ \\
\hline $12-\mathrm{OMe}$ & & & & & 56.3 & $3.88 \mathrm{~s}$ \\
\hline$\underline{\mathrm{CO}_{2} \mathrm{Me}}$ & 168.4 & & 168.1 & & 168.4 & \\
\hline $\mathrm{CO}_{2} \mathrm{Me}$ & 51.7 & $3.79, \mathrm{~s}$ & 51.8 & $3.79 \mathrm{~s}$ & 51.8 & $3.78 \mathrm{~s}$ \\
\hline
\end{tabular}

${ }^{a}$ Recorded at 600 and $150 \mathrm{MHz}$

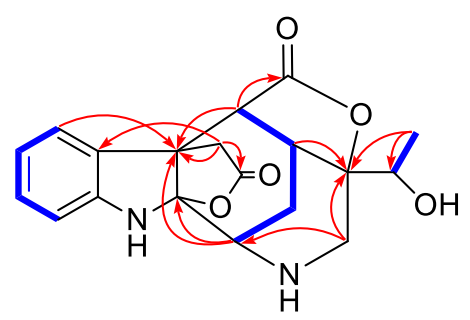

1 and 2

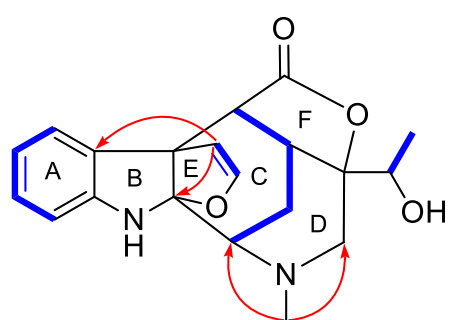

3

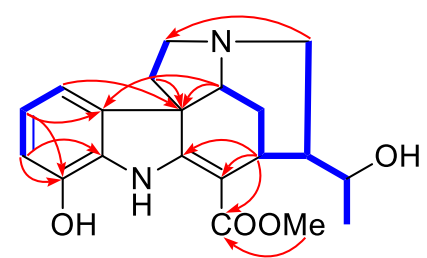

4

Fig. 2 Key ${ }^{1} \mathrm{H}-{ }^{1} \mathrm{H}$ COSY $(\longrightarrow)$ and $\operatorname{HMBC}(\longrightarrow)$ correlations for $\mathbf{1}-\mathbf{4}$

its HRESIMS data $\left(\mathrm{m} / \mathrm{z}\right.$ 357.1810, $[\mathrm{M}+\mathrm{H}]^{+}$, calcd for $\mathrm{C}_{20} \mathrm{H}_{25} \mathrm{~N}_{2} \mathrm{O}_{4}$ 357.1810), which indicated 10 degrees of unsaturation. Its IR spectrum displayed characteristic absorptions attributing to amino/hydroxyl $\left(3417 \mathrm{~cm}^{-1}\right)$, double bond $\left(1678 \mathrm{~cm}^{-1}\right)$, and aromatic ring (1620, $1440 \mathrm{~cm}^{-1}$ ) functionalities. The ${ }^{1} \mathrm{H}$ NMR spectrum (Table 3) showed the presence of a 1, 2, 3-trisubstituted aromatic moiety due to the signals of three contiguous aromatic hydrogens $\left(\delta_{\mathrm{H}} 6.89, \mathrm{~d}, J=7.5 \mathrm{~Hz}, \mathrm{H}-9 ; 7.14\right.$, t, $J=7.8 \mathrm{~Hz}, \mathrm{H}-10 ; 6.82, \mathrm{~d}, J=8.1 \mathrm{~Hz}, \mathrm{H}-11)$ and two methyls $\left(\delta_{\mathrm{H}} 3.79\right.$ and 1.32$)$. The ${ }^{13} \mathrm{C}$ NMR spectrum (Table 3) displayed a total of 20 carbon signals, which were classified as two methyls, four methylenes, seven methines, and seven quaternary carbons, respectively. The 


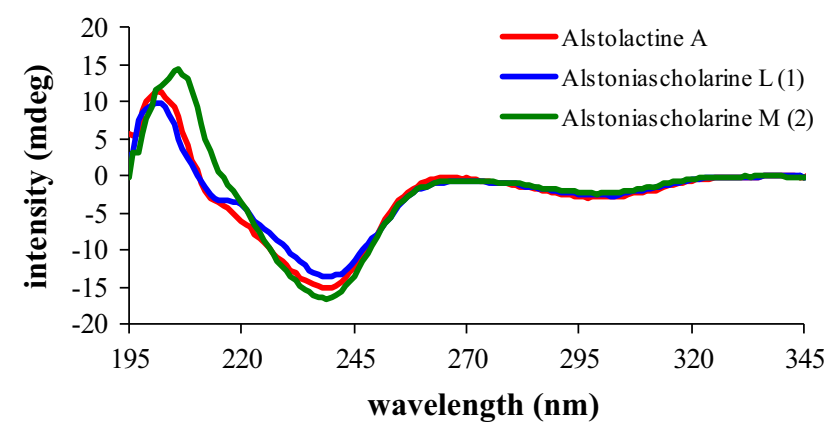

Fig. 3 Experimental CD spectra of alstolactine A (red), 1 (blue) and 2 (green). (Color figure online)

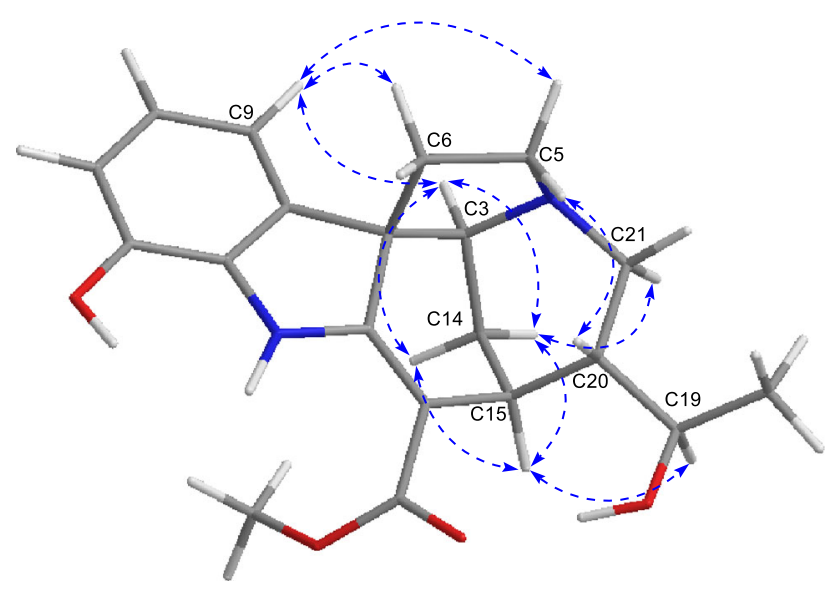

Fig. 4 Key ROESY $(\nleftarrow-\rightarrow)$ correlations for alkaloids 4-6

presence of conjugated ester functionality was supported by the observed carbon signals at $\delta_{\mathrm{C}} 168.4$ and 51.7, while the signals due to the two olefinic quaternary carbons at $\delta_{\mathrm{C}}$ $165.6(\mathrm{C}-2)$ and 105.3 (C-16) are consistent with the presence of a $\beta$-anilinoacrylate moiety [8]. One downfield signal at $\delta_{\mathrm{C}} 69.0$ was associated with the presence of oxymethine. The COSY and HMQC data (Figs. 2, 3) disclosed the following partial structures, viz., $\mathrm{NCH}_{2} \mathrm{CH}_{2}$, $\mathrm{NCHCH}_{2} \mathrm{CHCHCH}_{2}$, and $\mathrm{CHCHCH}_{3}$, corresponding to the C-5-C-6, C-3-C-14-C-15-C-20-C-21, and C-20-C-19-C18 fragments, respectively. The above NMR data and the partial structures from the COSY spectrum indicated a similarity $N(4)$-demethylalstogustine (25) except for the observed difference in the aromatic region. The replacement of $\mathrm{H}$ by $\mathrm{OH}$ at $\mathrm{C}-12$ was verified by the $\mathrm{HMBC}$ correlations of $\delta_{\mathrm{H}} 6.82(\mathrm{H}-10)$ and $6.74(\mathrm{H}-11)$ with $\delta_{\mathrm{C}}$ 143.3 (C-12). The relative configurations at the various stereogenic centers were established from ROEs and by comparison of the ${ }^{13} \mathrm{C}$ NMR spectra with the reported values. The ROESY spectrum (Fig. 4) displayed cross peaks of $\mathrm{H}-3 / \mathrm{H}-9, \mathrm{H}-3 / \mathrm{H}-5 \mathrm{~b}, \mathrm{H}-3 / \mathrm{H}-6 \mathrm{~b}, \mathrm{H}-3 / \mathrm{H}_{2}-14, \mathrm{H}_{2}-14 /$ $\mathrm{H}-15$ indicating the relative configurations of $\mathrm{C}-7$ and $\mathrm{C}-3$, which also in turn allowed the orientation of $\mathrm{H}-15$ to be assigned as $\alpha$. The preferred boat conformation adopted by the piperidine ring $\mathrm{D}$ could be deduced from the observed H-14a/H-21a ROE correlation [16]. Likewise, the key ROE correlations of $\mathrm{H}-9 / \mathrm{H}-6 \mathrm{~b}$ and $\mathrm{H}-6 \mathrm{a} / \mathrm{H}-20$ suggested a $\beta$ orientation for $\mathrm{H}-20$. Characteristic chemical shifts of $\mathrm{C}-16$ $(\delta$ 105.6) and $\mathrm{C}-19$ (69.0) suggested that the configuration of $\mathrm{C}-19$ in 4 should be $R$, which was consistent with that of alstogustine $\left(\delta_{\mathrm{C}} 105.3,68.8\right)$ [17], rather than that of 19-epi-alstogustine $\left(\delta_{\mathrm{C}} 104.8,70.6\right)$ [17]. On the basis of the above evidences, the structure of $\mathbf{4}$ was deduced to be as shown in Fig. 1 and named as alstoniascholarine O.

Alkaloid 5 exhibited a molecular ion peak at $\mathrm{m} / z 372.1676$ in its HREIMS spectrum, indicating the molecular formula of $\mathrm{C}_{20} \mathrm{H}_{24} \mathrm{~N}_{2} \mathrm{O}_{5}$ with sixteen mass units higher than that of 4. Examination of the ${ }^{1} \mathrm{H}$ NMR spectrum revealed four downfield shifts for the protons $\mathrm{H}-3\left(\delta_{\mathrm{H}}\right.$ 4.83), $\mathrm{H}-5\left(\delta_{\mathrm{H}} 4.08\right)$, and $\mathrm{H}-21\left(\delta_{\mathrm{H}} 4.00\right.$ and 3.81$)$, while the ${ }^{13} \mathrm{C}$ NMR data exhibited noticeable downfield shifts involving $\mathrm{C}-3\left(\delta_{\mathrm{C}} 78.0\right), \mathrm{C}-5\left(\delta_{\mathrm{C}} 66.8\right)$, and C-21 $\left(\delta_{\mathrm{C}} 64.1\right)$, when compared to those of 4 . These features are characteristic of $N(4)$-oxides, and this conclusion was further confirmed by the HMBC correlations of $\delta_{\mathrm{H}} 4.08\left(\mathrm{H}_{2}-5\right)$, $2.62(\mathrm{H}-14 \mathrm{a})$, and $4.00(\mathrm{H}-21 \mathrm{a})$ with $\delta_{\mathrm{C}} 78.0(\mathrm{~d}, \mathrm{C}-3)$. The ROESY correlations (Fig. 4) indicated that the relative configuration of $\mathbf{5}$ was the same as that of $\mathbf{4}$. Other parts of 5 were identical to those of $\mathbf{4}$ as secured by detailed analysis of extensive 2D NMR spectral data of $\mathbf{5}$. Thus, the structure of alkaloid $\mathbf{5}$ was determined to be as shown in Fig. 1 and named alstoniascholarine P.

Alkaloid $\mathbf{6}$ was deduced to have the molecular formula $\mathrm{C}_{21} \mathrm{H}_{26} \mathrm{~N}_{2} \mathrm{O}_{5}$, as indicated by the observed ion peak at $\mathrm{m} / \mathrm{z}, 386.1847[\mathrm{M}]^{+}$in its HREIMS data. The IR, UV and 1D NMR spectra of $\mathbf{6}$ were similar to those of $\mathbf{5}$, which suggested that $\mathbf{6}$ was also a strychnan type indole alkaloid. The ${ }^{1} \mathrm{H}$ and ${ }^{13} \mathrm{C}$ NMR data (Table 3 ) of 6 exhibited high similarities with those of $N^{\mathrm{b}}$-demethylalstogustine $N$-oxide (25), except for the loss of one aromatic proton and the existence of an additional methoxy group $\left(\delta_{\mathrm{C}} 56.3, \delta_{\mathrm{H}}\right.$ 3.88). By comparing the ${ }^{1} \mathrm{H}$ and ${ }^{13} \mathrm{C}$ NMR spectral data of 6 with those of 25, the C-12 carbon signal was significantly deshielded, while the C-11 and C-13 carbon signals were relatively shielded, suggesting that the methoxy was attached to C-12. This conclusion was further confirmed by the correlation of methoxy protons at $\delta_{\mathrm{H}} 3.88$ with $\mathrm{C}-12$ $\left(\delta_{\mathrm{C}} 146.2\right)$ in the HMBC spectrum. Complete analysis of 2D NMR spectral data of $\mathbf{6}$ suggested that its other parts were the same to those of $\mathbf{4}$ and $\mathbf{5}$. Hence, the structure of alkaloid $\mathbf{6}$ was assigned as shown in Fig. 1 and named as alstoniascholarine Q.

The known alkaloids picrinine (7) [18], strictamine (8) [19], tubotawine (9) [20], alstolucine D (10) [8], nareline (11) [21], picralinal (12) [18], isoalschomine (13) [18], polyneuridine (14) [22], burnamine (15) [23], echitamidine 
(16) [24], scholarisine I (17) [25], 19,20-Z-vallesamine (18) [26], 19,20-E-vallesamine (19) [26], scholaricine (20) [27], 19-epi-scholaricine (21) [16], pseudoakuammigine $N^{\mathrm{b}}$-oxide (22) [28], tubotawine $N^{\mathrm{b}}$-oxide (23) [29], vallesamine $N^{\mathrm{b}}$-oxide (24) [16], and $N^{\mathrm{b}}$-demethylalstogustine $N$ oxide (25) [30], were identified by comparison of their spectroscopic data with those reported in the literature.

Considering the various bioactivities of the chemical constituents from A. scholaris reported previously [5], six new alkaloids (1-6) were evaluated for their cytotoxic and neurite outgrowth-promoting activities. Unfortunately, the alkaloids 1-6 neither showed cytotoxic activity against five human cancer cell lines (SW-480, SMMC-7721, HL-60, MCF-7, and A-549), nor exhibited neurite outgrowth-promoting activity.

\section{Experimental Section}

\subsection{General Experimental Procedures}

Optical rotations were recorded on a JASCO P-1020 polarimeter. UV spectra were measured on a Shimadzu UV-2401PC spectrophotometer. IR spectra were performed on a Bruker FT-IR Tensor-27 infrared spectrophotometer with $\mathrm{KBr}$ discs. NMR spectroscopic data were obtained on Bruker AM-400 and DRX-500 spectrometers using TMS as an internal standard. Unless otherwise specified, chemical shifts $(\delta)$ were expressed in ppm with reference to the solvent signals. ESIMS spectra were performed on Waters Xevo TQ-S and Bruker HCT/Esquire mass spectrometers; HREIMS and HRESIMS analyses were carried out on Waters AutoSpec Premier P776 and Agilent 6540 UHD Accurate-Mass Q-TOF LC/MS mass spectrometers, respectively. Column chromatography (CC) was conducted on silica gel (200-300 mesh, Qingdao Marine Chemical Co., Ltd., Qingdao, People's Republic of China), RP-18 gel (20-45 $\mu \mathrm{m}$, Fuji Silysia Chemical Ltd., Japan), and Sephadex LH-20 (GE Healthcare Bio-sciences AB, Sala, Sweden). Fractions were monitored by TLC (GF 254, Qingdao Marine Chemical Co., Ltd., Qingdao), and spots were visualized by Dragendorff's reagent.

\subsection{Plant Material}

The inadequately dried leaves of A. scholaris were collected in June 2013 in Pu'er city of Yunnan Province, P. R. China and identified by Dr. Xiao-Dong Luo, Kunming Institute of Botany, Chinese Academy of Sciences. A voucher specimen (No. Luo20130720) has been deposited in the State Key Laboratory of Phytochemistry and Plant Resources in West China, Kunming Institute of Botany, Chinese Academy of Sciences.

\subsection{Extraction and Isolation}

The inadequately dried leaves $(40 \mathrm{~kg})$ of $A$. scholaris were extracted with $\mathrm{MeOH}$ at room temperature, and the solvent was evaporated in vacuo. The extract was dissolved in $0.3 \% \mathrm{HCl}$ solution and then partitioned with EtOAc three times. The acidic water-soluble material, subsequently basified with $5 \%$ ammonia solution to $\mathrm{pH} 9-10$, was repeatedly partitioned with EtOAc three times to give the crude alkaloid extract $(155 \mathrm{~g})$. The alkaloid extract was subjected to a silica gel column and eluted with $\mathrm{CHCl}_{3}-$ $\mathrm{MeOH}(30: 1,15: 1,10: 1,5: 1,1: 1)$ to afford fractions I-V. Fraction I ( $40.0 \mathrm{~g})$ was separated by RP-18 CC, eluted with $\mathrm{MeOH}-\mathrm{H}_{2} \mathrm{O}(55: 1 \rightarrow 100: 1)$ to give five subfractions (Fr. I-I to Fr. I-V). Fraction I-II ( $3.8 \mathrm{~g})$ was further separated by silica gel $\mathrm{CC}$, eluted with $\mathrm{CHCl}_{3}$-acetone $(10: 1 \rightarrow 5: 1)$ to yield alkaloids $\mathbf{8}(25 \mathrm{mg}), \mathbf{9}(18 \mathrm{mg}), \mathbf{1 0}(38 \mathrm{mg})$, and $\mathbf{1 1}$ $(123 \mathrm{mg})$. Fraction I-III (16 g) was subjected to RP-18 CC, eluted with $\mathrm{MeOH}-\mathrm{H}_{2} \mathrm{O}(75: 25 \rightarrow 95: 5)$ to obtain alkaloids $\mathbf{1}(18 \mathrm{mg}), \mathbf{2}(20 \mathrm{mg})$, and $\mathbf{7}(9.8 \mathrm{~g})$. Fraction II (10 g) was separated by RP-18 CC, eluted with $\mathrm{MeOH}-\mathrm{H}_{2} \mathrm{O}$ (50:50-80:20) and subsequently purified by Sephadex LH$20 \mathrm{CC}$ to yield alkaloids $\mathbf{1 2}(17 \mathrm{mg}), \mathbf{1 3}(12 \mathrm{mg}), \mathbf{1 4}$ $(10 \mathrm{mg}), \mathbf{1 5}(15 \mathrm{mg})$ and $\mathbf{1 6}(32 \mathrm{mg})$. Fraction III $(35 \mathrm{~g})$ was subjected to RP-18 CC and eluted with $\mathrm{MeOH}-\mathrm{H}_{2} \mathrm{O}$ $(40: 60 \rightarrow 65: 35)$ to obtain five fractions (Fr. III-I to Fr. III-V). Fraction III-II $(200 \mathrm{mg})$ was chromatographed repeatedly over silica gel $\mathrm{CC}$, eluted with $\mathrm{CHCl}_{3}-\mathrm{MeOH}$ $(12: 1 \rightarrow 10: 1)$ to give alkaloids $\mathbf{3}(12 \mathrm{mg})$ and $\mathbf{1 7}(8 \mathrm{mg})$. In the same way, alkaloid 20 (6.5 g) was obtained from fraction III-III $(8.2 \mathrm{~g})$ by silica gel $\mathrm{CC}$ and eluted with $\mathrm{CHCl}_{3}-\mathrm{MeOH}(12: 1 \rightarrow 10: 1)$. Fraction III-IV $(1 \mathrm{~g})$ was separated by RP-18 CC, eluted with $\mathrm{MeOH}-\mathrm{H}_{2} \mathrm{O}$ $(35: 65 \rightarrow 60: 40)$ to afford alkaloids 4 (7 mg), $18(45 \mathrm{mg})$, $19(18 \mathrm{mg})$, and $21(85 \mathrm{mg})$. Fraction IV (14 g) was separated over RP-18 CC, eluted with $\mathrm{MeOH}-\mathrm{H}_{2} \mathrm{O}$ $(25: 75 \rightarrow 60: 40)$ to afford five fractions (Fr. IV-I to Fr. IV-V). Fraction IV-II (120 mg) was subjected to silica gel $\mathrm{CC}$, eluted with $\mathrm{CHCl}_{3}-\mathrm{MeOH}(8: 1 \rightarrow 5: 1)$ to yield alkaloid $22(15 \mathrm{mg})$. Fraction IV-III (200 mg) was purified by $\mathrm{RP}-18 \mathrm{CC}$, eluted with $\mathrm{MeOH}-\mathrm{H}_{2} \mathrm{O}(30: 70 \rightarrow 50: 50)$ to give alkaloids $\mathbf{2 3}(4 \mathrm{mg})$ and $\mathbf{2 4}(6 \mathrm{mg})$. Fraction IV-IV (300 mg) was subjected to RP-18 CC eluted with $\mathrm{MeOH}-$ $\mathrm{H}_{2} \mathrm{O}(25: 75 \rightarrow 50: 50)$ and further purified by silica gel CC eluted with $\mathrm{CHCl}_{3}-\mathrm{MeOH}(6: 1 \rightarrow 4: 1)$ to yield alkaloids 5 $(6 \mathrm{mg}), \mathbf{6}(8 \mathrm{mg})$ and $\mathbf{2 5}(6 \mathrm{mg})$.

\subsubsection{Alstoniascholarine L (1)}

White amorphous powder; $[\alpha]_{D}^{24}-121.1(c 0.1 \mathrm{MeOH})$; UV $(\mathrm{MeOH}) \lambda_{\max }(\log \varepsilon) 204$ (4.45), 240 (3.87), 298 (3.49) nm; IR (KBr) $v_{\max } 3440,2924,1748,1630,1612,1473$, 
$1090 \mathrm{~cm}^{-1} ; \mathrm{CD}(\mathrm{MeOH}) \lambda_{\max }(\Delta \varepsilon) 202 \quad(+8.1), 239$ (-10.8), $302(-2.1) \mathrm{nm} ;{ }^{1} \mathrm{H}\left(400 \mathrm{MHz}, \mathrm{CD}_{3} \mathrm{OD}\right)$ and ${ }^{13} \mathrm{C}$ NMR (100 MHz, $\left.\mathrm{CD}_{3} \mathrm{OD}\right)$ data, see Table 2; ESIMS $\mathrm{m} /$ z $379[\mathrm{M}+\mathrm{Na}]^{+}$; HREIMS $m / z 356.1366\left([\mathrm{M}]^{+}\right.$calcd for $\mathrm{C}_{19} \mathrm{H}_{20} \mathrm{~N}_{2} \mathrm{O}_{5}, 356.1372$ ).

\subsubsection{Alstoniascholarine M (2)}

White amorphous powder; $[\alpha]_{D}^{24}-117.1$ ( $\left.0.1 \mathrm{MeOH}\right)$; UV (MeOH) $\lambda_{\max }(\log \varepsilon) 204$ (4.48), 240 (3.90), 298 (3.52) nm; IR $(\mathrm{KBr}) v_{\max } 3441,2923,1748,1631,1474,1241$, $1085 \mathrm{~cm}^{-1} ; \mathrm{CD}(\mathrm{MeOH}) \lambda_{\max }(\Delta \varepsilon) 202(+8.3), 239$ (-11.6), $302(-2.4) \mathrm{nm} ;{ }^{1} \mathrm{H}\left(400 \mathrm{MHz}, \mathrm{CD}_{3} \mathrm{OD}\right)$ and ${ }^{13} \mathrm{C}$ NMR (100 MHz, $\left.\mathrm{CD}_{3} \mathrm{OD}\right)$ data, see Table 2; ESIMS m/ z $379[\mathrm{M}+\mathrm{Na}]^{+}$; HREIMS $m / z 356.1358\left([\mathrm{M}]^{+}\right.$calcd for $\mathrm{C}_{19} \mathrm{H}_{20} \mathrm{~N}_{2} \mathrm{O}_{5}, 356.1372$ ).

\subsubsection{Alstoniascholarine N (3)}

White amorphous powder; $[\alpha]_{D}^{23}+2.7$ (c $\left.0.1 \mathrm{MeOH}\right)$; UV (MeOH) $\lambda_{\max }(\log \varepsilon) 204$ (4.38), 229 (4.35), 291 (3.63) nm; IR $(\mathrm{KBr}) v_{\max } 3426,2976,1764,1640,1511,1244$, $1104 \mathrm{~cm}^{-1} ;{ }^{1} \mathrm{H} \quad\left(600 \mathrm{MHz}, \mathrm{CD}_{3} \mathrm{OD}\right)$ and ${ }^{13} \mathrm{C} \mathrm{NMR}$ (150 MHz, $\mathrm{CD}_{3} \mathrm{OD}$ ) data, see Table 2; ESIMS $\mathrm{m} / \mathrm{z} 377$ $[\mathrm{M}+\mathrm{Na}]^{+}$; HREIMS $\mathrm{m} / \mathrm{z} 354.1577\left([\mathrm{M}]^{+}\right.$calcd for $\mathrm{C}_{20} \mathrm{H}_{22} \mathrm{~N}_{2} \mathrm{O}_{4}, 354.1580$ ).

\subsubsection{Alstoniascholarine $O$ (4)}

White amorphous powder; $[\alpha]_{D}^{23}-348.7$ ( $\left.0.1 \mathrm{MeOH}\right)$; UV $(\mathrm{MeOH}) \lambda_{\max }(\log \varepsilon) 213$ (4.09), 230 (4.00), 289 (3.61), 337 (4.06) nm; IR (KBr) $v_{\max } 3417,2977,1678,1620$, 1440, 1260, $1074 \mathrm{~cm}^{-1} ;{ }^{1} \mathrm{H}\left(600 \mathrm{MHz}, \mathrm{CD}_{3} \mathrm{OD}\right)$ and ${ }^{13} \mathrm{C}$ NMR (150 MHz, $\left.\mathrm{CD}_{3} \mathrm{OD}\right)$ data, see Table 3; ESIMS $m / z 357[\mathrm{M}+\mathrm{H}]^{+}$; HRESIMS $m / z 357.1810\left([\mathrm{M}+\mathrm{H}]^{+}\right.$ calcd for $\mathrm{C}_{20} \mathrm{H}_{25} \mathrm{~N}_{2} \mathrm{O}_{4}, 357.1809$ ).

\subsubsection{Alstoniascholarine P (5)}

White amorphous powder; $[\alpha]_{D}^{23}-329.3$ ( $\left.0.1 \mathrm{MeOH}\right)$; UV $(\mathrm{MeOH}) \lambda_{\max }(\log \varepsilon) 211$ (4.12), 287 (3.60), 336 (3.98) nm; IR $(\mathrm{KBr}) v_{\max } 3431,2977,1680,1621,1439,1202$, $1059 \mathrm{~cm}^{-1} ;{ }^{1} \mathrm{H}\left(600 \mathrm{MHz}, \mathrm{CD}_{3} \mathrm{OD}\right)$ and ${ }^{13} \mathrm{C} \mathrm{NMR}$ (150 MHz, $\mathrm{CD}_{3} \mathrm{OD}$ ) data, see Table 3; ESIMS $\mathrm{m} / \mathrm{z} 373$ $[\mathrm{M}+\mathrm{H}]^{+}$; HREIMS $m / z 372.1676\left([\mathrm{M}]^{+}\right.$calcd for $\mathrm{C}_{20} \mathrm{H}_{24} \mathrm{~N}_{2} \mathrm{O}_{5}, 372.1685$ ).

\subsubsection{Alstoniascholarine $Q$ (6)}

White amorphous powder; $[\alpha]_{D}^{24}-298.7$ ( c $\left.0.12 \mathrm{MeOH}\right)$; UV (MeOH) $\lambda_{\max }(\log \varepsilon) 210$ (4.21), 287 (3.76), 334 (4.06) $\mathrm{nm}$; IR (KBr) $v_{\max } 3438,2965,1681,1615,1461,1266$,
$1060 \mathrm{~cm}^{-1} ;{ }^{1} \mathrm{H} \quad\left(600 \mathrm{MHz}, \quad \mathrm{CD}_{3} \mathrm{OD}\right)$ and ${ }^{13} \mathrm{C} \quad \mathrm{NMR}$ (150 MHz, CD $\left.{ }_{3} \mathrm{OD}\right)$ data, see Table 3; ESIMS $\mathrm{m} / \mathrm{z} 387$ $[\mathrm{M}+\mathrm{H}]^{+}$; HREIMS $\mathrm{m} / \mathrm{z} 386.1847\left([\mathrm{M}]^{+}\right.$calcd for $\mathrm{C}_{21} \mathrm{H}_{26} \mathrm{~N}_{2} \mathrm{O}_{5}, 386.1842$ ).

\subsection{Antitussive Effects Against Ammonia-Induced Cough}

The antitussive assay was performed using the technique as described in the literature [31]. ICR (Institute of Cancer Research) mice of either sex (19-24 g) were purchased from Kunming Medical College (license number SYXK 2005-0001). All mice were housed at room temperature $\left(20-25^{\circ} \mathrm{C}\right)$ and constant humidity (40-70\%) under a $12 \mathrm{~h}$ light-dark cycle in SPF (Specific Pathogen Free) grade laboratory. The animal study was performed according to the international rules considering animal experiments and the internationally accepted ethical principles for laboratory animal use and care. The mice were divided randomly, of which 12 mice per group. The negative control group of animals was treated with distilled water orally, and the positive control was treated with codeine phosphate, the remaining groups were treated with test samples. Antitussive activity was investigated on a classical mouse cough model induced by ammonia liquor. Briefly, each mouse was placed in a $300 \mathrm{~mL}$ special glass chamber and exposed to $40 \mu \mathrm{L} 25 \%$ ammonia solution. The cough frequency produced during 2 min exposure period was counted. In the second assay for alkaloids, cough frequency and latent period of cough were recorded.

\subsection{Cytotoxic Activity Assay}

The following human cancer cell lines were used: SW-480, SMMC-7721, HL-60, MCF-7, and A-549. All cells were cultured in RPMI-1640 or DMEM medium (Hyclone, Logan, UT), supplemented with $10 \%$ fetal bovine serum (Hyclone) at $37{ }^{\circ} \mathrm{C}$ in a humidified atmosphere with $5 \%$ $\mathrm{CO}_{2}$. Cell viability was assessed by conducting colorimetric measurements of the amount of insoluble formazan formed in living cells based on the reduction of 3-(4, 5-dimethylthiazol-2-yl)-2, 5-diphenyltetrazolium bromide (MTT) (Sigma, St. Louis, MO) [32]. Briefly, $100 \mu \mathrm{L}$ of adherent cells was seeded into each well of a 96-well cell culture plate and allowed to adhere for $12 \mathrm{~h}$ before drug addition, while suspended cells were seeded just before drug addition, both with an initial density of $1 \times 10^{5}$ cells/ $\mathrm{mL}$ in $100 \mu \mathrm{L}$ of medium. Each cell line was exposed to the test compound at various concentrations in triplicate for $48 \mathrm{~h}$, with cisplatin and paclitaxel (Sigma) as positive controls. After the incubation, MTT $(100 \mu \mathrm{g})$ was added to each well, and the incubation continued for $4 \mathrm{~h}$ at $37{ }^{\circ} \mathrm{C}$. The cells were lysed with $100 \mu \mathrm{L}$ of $20 \%$ SDS-50 \% DMF 
after removal of $100 \mu \mathrm{L}$ of medium. The optical density of the lysate was measured at $595 \mathrm{~nm}$ in a 96-well Microtiter plate reader (Bio-Rad 680).

\subsection{Neurite Outgrowth-Promoting Activity Assay}

The neurotrophic activities of the test compounds were examined according to an assay using PC12 cells as reported elsewhere [33]. Briefly, PC12 cells were maintained in F12 medium supplemented with $12.5 \%$ horse serum (HS), and $2.5 \%$ fetal bovine serum (FBS), and incubated at $5 \% \mathrm{CO}_{2}$ and $37{ }^{\circ} \mathrm{C}$. Test compounds were dissolved in DMSO. For the neurite outgrowth-promoting activity bioassay, PC12 cells were seeded at a density of $5 \times 10^{4}$ cells $/ \mathrm{mL}$ in 48 -well plate coated with poly-L-lysine. After $24 \mathrm{~h}$, the medium was changed to that containing $10 \mu \mathrm{M}$ of each test compounds plus $5 \mathrm{ng} / \mathrm{mL}$ NGF, or various concentrations of NGF $(50 \mathrm{ng} / \mathrm{mL}$ for the positive control, $5 \mathrm{ng} / \mathrm{mL}$ for the negative control). The final concentration of DMSO was $0.05 \%$, and the same concentration of DMSO was added into the negative control. After $72 \mathrm{~h}$ incubation, the neurite outgrowth was assessed under a phase contrast microscope. Neurite processes with a length equal to or greater than the diameter of the neuron cell body were scored as neurite bearing cells. The ratio of the neurite-bearing cells to total cells (with at least 100 cells examined/view area; 5 viewing area/well) was determined and expressed as a percentage.

Acknowledgments The authors are grateful to the Natural Science Foundation of China (81225024), Collaborative Innovation Center of Southwest EthnicMedicine (Guangxi Normal University), (CICSEM 2013-A), the Ministry of Science and Technology of the People's Republic of China (2014ZX09301307-003), and the Chinese Academy of Sciences (KSZD-EW-Z-004-03) for partial financial support.

\section{Compliance with Ethical Standards}

Conflict of Interest The authors declare no conflicts of interest in this work.

Open Access This article is distributed under the terms of the Creative Commons Attribution 4.0 International License (http:// creativecommons.org/licenses/by/4.0/), which permits unrestricted use, distribution, and reproduction in any medium, provided you give appropriate credit to the original author(s) and the source, provide a link to the Creative Commons license, and indicate if changes were made.

\section{References}

1. Atta-ur-Rahman, K.A. Alvi, Phytochemistry 26, 2139-2142 (1987)

2. T.S. Kam, K.T. Nyeoh, K.M. Sim, K. Yoganathan, Phytochemistry 45, 1303-1305 (1997)
3. A.P.G. Macabeo, K. Krohn, D. Gehle, R.W. Read, J.J. Brophy, G.A. Cordell, S.G. Franzblau, A.M. Aguinaldo, Phytochemistry 66, 1158-1162 (2005)

4. L. Zhang, C.J. Zhang, D.B. Zhang, J. Wen, X.W. Zhao, Y. Li, K. Gao, Tetrahedron Lett. 55, 1815-1817 (2014)

5. M.S. Khyade, D.M. Kasote, N.P. Vaikos, J. Ethnopharmacol. 153, 1-18 (2014)

6. G.C. Jagetia, M.S. Baliga, J. Ethnopharmacol. 96, 37-42 (2005)

7. M.R. Khan, A.D. Omoloso, M. Kihara, Fitoterapia 74, 736-740 (2003)

8. J.H. Shang, X.H. Cai, T. Feng, Y.L. Zhao, J.K. Wang, L.Y. Zhang, M. Yan, X.D. Luo, J. Ethnopharmacol. 129, 174-181 (2010)

9. S. Channa, A. Dar, S. Ahmed, Atta-ur-Rahman, J. Ethnopharmacol. 97, 469-476 (2005)

10. X.H. Cai, Z.Z. Du, X.D. Luo, Org. Lett. 9, 1817-1820 (2007)

11. X.H. Cai, Q.G. Tan, Y.P. Liu, T. Feng, Z.Z. Du, W.Q. Li, X.D. Luo, Org. Lett. 10, 577-580 (2008)

12. X.H. Cai, Y.P. Liu, T. Feng, X.D. Luo, Chin. J. Nat. Med. 6, 20-22 (2008)

13. T. Feng, X.H. Cai, P.J. Zhao, Z.Z. Du, W.Q. Li, X.D. Luo, Planta Med. 75, 1537-1541 (2009)

14. X.W. Yang, X.J. Qin, Y.L. Zhao, P.K. Lunga, X.N. Li, S.Z. Jiang, G.G. Cheng, Y.P. Liu, X.D. Luo, Tetrahedron Lett. 55, 4593-4596 (2014)

15. X.J. Qin, Y.L. Zhao, P.K. Lunga, X.W. Yang, C.W. Song, G.G. Cheng, L. Liu, Y.Y. Chen, Y.P. Liu, X.D. Luo, Tetrahedron 71, 4372-4378 (2015)

16. T. Yamauchi, F. Abe, R.F. Chen, G.I. Nonaka, T. Santisuk, W.G. Padolina, Phytochemistry 29, 3547-3553 (1990)

17. M.E. Kuehne, F. Xu, C.S. Brook, J. Org. Chem. 59, 7803-7806 (1994)

18. F. Abe, R.F. Chen, T. Yamauchi, N. Marubayashi, I. Ueda, Chem. Pharm. Bull. 37, 887-890 (1989)

19. Habib-ur-Rehman Atta-ur-Rahman, Planta Med. 3, 230-231 (1986)

20. T. Yamauchi, F. Abe, W.G. Padolina, F.M. Dayrit, Phytochemistry 29, 3321-3325 (1990)

21. Y. Morita, M. Hesse, H. Schmid, A. Banerji, J. Banerji, A. Chatterjee, W.E. Oberhänsli, Helv. Chim. Acta 60, 1419-1434 (1977)

22. L.D. Antonaccio, N.A. Pereira, B. Gilbert, H. Vorbrueggen, H. Budzikiewicz, J.M. Wilson, L.J. Durham, C. Djerassi, J. Am. Chem. Soc. 84, 2161-2169 (1962)

23. R.H. Burnell, J.D. Medina, Phytochemistry 7, 2045-2051 (1968)

24. D. Keawpradub, H. Takayama, N. Aimi, S.I. Sakai, Phytochemistry 37, 1745-1749 (1994)

25. X.W. Yang, X.D. Luo, P.K. Lunga, Y.L. Zhao, X.J. Qin, Y.Y. Chen, L. Liu, X.N. Li, Y.P. Liu, Tetrahedron 71, 3694-3698 (2015)

26. K.A. Atta-ur-Rahman, S.A. Alvi, W. Abbas, Voeter. Heterocycles 26, 413-419 (1987)

27. Atta-ur-Rahman, M. Asif, M. Ghazala, J. Fatima, K.A. Alvi, Phytochemistry 24, 2771-2773 (1985)

28. W.L. Hu, J.P. Zhu, M. Hesse, Planta Med. 55, 463-466 (1989)

29. M. Pinar, U. Renner, M. Hesse, H. Schmid, Helv. Chim. Acta 55, 2972-2974 (1972)

30. A.A. Salim, M.J. Garson, D.J. Craik, J. Nat. Prod. 67, 1591-1594 (2004)

31. S.Y. Xu, R.L. Bian, X. Chen, Pharmacological Experiment Methodology (People's Medical Publishing House, Beijing, 1991), p. 1167

32. T. Mosmann, J. Immunol. Methods 65, 55-63 (1983)

33. A. Pradines, M. Magazin, P. Schiltz, G. Le Fur, D. Caput, P. Ferrara, J. Neurochem. 64, 1954-1964 (1995) 